\title{
DETERMINANTS OF SUPERPOWER ECONOMIC GROWTH
}

\author{
Nur Rachmat Arifin ${ }^{1}$, Hawa' Hidayatul Hikmiyah ${ }^{1}$, Hariyanto $^{2}$ \\ Universitas Islam Zainul Hasan Genggong ${ }^{1}$ \\ Jl. PB. Sudriman No. 360 Semampir Kraksaan Probolinggo \\ Universitas Airlangga ${ }^{2}$ \\ Jl. Mayjen Prof. Dr. Moestopo No.47, Pacar Kembang, Kec. Tambaksari, Kota Surabaya \\ nurrachmatarifin05@gmail.com ${ }^{1}$ \\ hawahidayatulhikmiyah@gmail.com ${ }^{1}$ \\ hariyantodkk@gmail.com ${ }^{2}$
}

\begin{abstract}
Countries in various parts of the world make economic growth the initial goal of achieving a country, one indicator used to view economic growth and one of which is the increase in Gross Domestic Product. GDP is the total value of the production of goods or services in a country for one year. This study aims to see what are the factors that influence the economic growth of the superpowers with exports, inflation, and exchange rates, and unemployment as the independent variable and GDP as the dependent variable. This research uses secondary data in the form of a combination of cross-sectional data and time series (panel data). The analytical method used is a panel data regression with a flat model model, covering six countries, namely America, China, India, Korea, Japan, and Thailand during the period 1991-2019. The results show that the Export variable, Exchange Rate, has a significant effect on GDP. Meanwhile, two independent variables, namely inflation, unemployment, did not have a significant effect on the dependent variable.
\end{abstract}

Keyword: Export Superpower, Inflation, Exchange Rate, Unemployment 


\section{INTRODUCTION}

The success of a country's development can be seen from the level of its economic growth, each country always sets a stable economic growth rate target in the country's development planning and goals. Government policies in reducing inequality in economic growth and determining economic growth (Benabou, 2000) Policymakers such as the government must know the right strategy to use in overcoming a recession (Abdul, 2019). Economic growth can be interpreted as a process of increasing the amount of production of an economy as reflected in an increase in national income (Jhingan, 2010).

High economic growth can be carried out properly and sustainably, the results can be felt by all people, high income consists of minority groups in the community and low income becomes the majority among the community, submission of economic development obligations if it is delegated to high-income people, then they will be able to spur growth well. However, if the majority of low-income groups are chosen, the development results must be shared equally and this makes it less likely that the national Gross National Product can be achieved at a higher level (Todaro \& Smith, 2003).

According to Bhagwati, an increase in income has an effect on increasing GDP, and an increase in income facilitates more in the trade sector (Bhagwati, 1988). So, the results show a "virtuous circle." This type of feedback has also been noted by Grossman and Helpman (1991) in their model of north-south trade. It can also be mentioned that only a limited number of studies are available for the country panel (Muinelo-Gallo and Roca-Sagales (2013) 'for the OECD).

One of the most challenging public policy topics in reducing economic disparities, namely government policies play an important role in reducing economic inequality and determining the effect on the rate of economic growth or not (Benabou, 2000). The literature relating to political economy provides a theoretical background for the empirical model, in which fiscal policy, inequality, and growth are determined in a democratic society.

Models of economic inequality and growth show that fiscal policy can play a major role in explaining the development of the two macroaggressions, in this context it is necessary to note one point that fiscal policy which is an endogenous variable reflects, through the political process, voter preferences for income distribution ( each individual behaves like an economic agent and a citizen of the distributive policy vote) (Drazen, 2000; Chapter 11). Previous political models show a negative relationship between inequality and growth under the assumption of perfect capital markets (Persson \& amp; Tabellini, 1994). This traditional notion seems less supportive of later empirical contributions using cross-country data. Second, in his work Benabou (2000) 'argues that fiscal policy choices can vary among different countries even though these countries may have 
similar preferences and technology as well as the same democratic political system. Muinelo-Gallo and Roca-Sagales (2013) analyzed the relationship between income inequality and economic growth through fiscal policy.

Economic development has to do with human resources, the quality of human resources can be seen from the development of the population, as an indicator in driving and inhibiting development, driving factors caused by the addition of labor and market expansion, the expansion of the market for goods and services is determined by people's income and population, the inhibiting factor states that population decreases productivity and there is a lot of unemployment (Sukirno, 2008: 68). Unemployment is economic variables, including the level of investment, the level of demand and the level of wages, some experts say that non-economic variables, namely education, which includes education level and type of education, are thought to affect reluctance to certain jobs (Todaro \& Smith, 2003).

According to Todaro (2003: 93), it has positive or negative values in increasing the population as an economic development that is dependent on ability, the economic system to absorb productively and utilize the additional workforce and an increase in the quality of education must also be balanced with equity.

Economic growth is the state of the economy of a country during a certain period where its development is better or increases than the previous period which can be seen from several indicators, one of which is GDP. GDP is the total value of the production of goods or services in a country for one year. The GDP levels of the countries Bahrain, Brunei Darussalam, and Malaysia are above the GDP levels of the countries of Indonesia and Sudan.

Romer (1990) hypothesized that expanding international trade increases the number of specific inputs, increasing the rate of growth because the economy becomes open to international trade. Buffie (1992) considers how export shocks can generate export-led growth.

A superpower or a superpower is a country that has power in the international political arena to influence global events which make decisions in international projects. Every superpower country will certainly carry out development in all fields and it is hoped that it can achieve high economic growth, can become a developed country, and can realize the goal of prospering society and even distribution of income in the context of realizing justice. The American economy is an economic structure that has been built by the United States so well, with the US dollar which is the largest currency that is the benchmark for exchange rates against other currencies in the world, the high exchange rate of the dollar compared to the currency of the country. others that make encouraging the strengthening of their economic system. The United States is still the strongest country in terms of military, the United States armed forces itself has spread throughout the world, 
in terms of technology, the United States is a country that has potential human resources so that it is able to create new discoveries, both in sophisticated science and technology. In terms of geography, the United States has a large area and a large and potential population, compared to other countries in the world.

There have been various studies carried out by previous research to determine the economic growth of the Oki country (Prastity, 2013) However, in previous research, many studies have examined the economic growth of Oki countries based on the country's ranking category, another study with the title determinants of economic growth in 4 ASEAN countries was conducted (Febryani \& Kusreni, 2017). The analysis of the results concluded that there is a significant influence between population growth and unemployment on economic growth in the four ASEAN countries, while inflation does not show a significant relationship with economic growth in the four ASEAN countries. However, in previous studies, many studies have examined the economic growth of Oki countries, developed countries, developing countries, however, it is very rare to examine the development of superpower countries' growth based on two categories, namely developed and developing countries. So this research wants to examine the analysis of the factors that influence superpowers, the research conducted by the author in the region, namely the United States, China, India, Korea, Japan, and Thailand. When compared to what is the background so that the GDP level of the country has a difference. So from this research wants to see what are the factors that affect the economic growth of the countries of the eight countries.

\section{LITERATURE REVIEW}

\section{Exports and GDP}

Exports and GDP The export sector plays a major role in economic development (Abdula \& Jaquet, 2002). Exports are various kinds of goods and services that have been produced domestically and sold abroad (Puspitasari, 2014). Exports are one of the foreign sources that are used as a reduction in income and can create labor and increase income (Fannoun, 2019). Various economists have stated that increasing exports can increase economic growth because exports are an element of GDP (Md. Sazib Miyan, 2019). Exports have an effect on economic growth from two sides, namely from the demand and supply side. In terms of demand, when the export sector employs a number of workers, it will affect the ability of the community to earn income due to the ability of companies to pay wages to workers so that it makes households to increase their consumption, but from the side of advice, exports can be a source of income. funding that encourages investment. Incentives to increase investment and technology will imply differences 
in productivity in supporting the export sector, in other words, the productivity of marginal factors is expected to be higher than other economic sectors (Sharma, A, 2005).

On the other hand, it can also increase the company's total production (He \& Zhang, 2009) (He, 2009). Research shows that exports have an effect on economic growth (Murindahabi, Qiang Li, Nisingizwe, \& Ekanayake, 2019: G. Dlamini \& V. Dlamini, 2019: Md. Sazib Miyan \& Kabir Biplob, 2019). However, there is research showing that exports have no influence on economic growth (Fakraoui \& Bakari, 2019: He \& Zhang, 2009).

H1. Exports have an effect on Economic Growth

\section{INFLATION AND GDP}

Inflation as a tendency in increasing the price level continuously over time (a sustained tendency for the general level of prices to rise over time). Based on this definition, an increase in general prices that occurs once in a while cannot be considered inflation (Nanga, 2001: 241). Inflation and GDP Inflation is a continuous increase in prices. Inflation that arises because of the demand for goods which is also known as demand pull inflation (Nainggolan, 2019). Inflation is caused by an increase in aggregate demand faster than supply so that it can increase the cost of goods and services. The aggregate supply and demand imbalance is related to the deficit of government. Inflation can also increase the price of goods and labor so that it can increase the selling price and cost of goods (Nurina, 2016). However, there is research which states that inflation has no effect on economic growth (Semuel, 2015). For the economy, high inflation can lead to economic instability, reduce investment, inhibit exports and may have an impact on increasing the unemployment rate. In terms of welfare, high inflation causes a decrease in the real income of the community, especially for workers who have a steady income, so that it has an impact on decreasing the level of public consumption and increasing poverty (Rukmana, 2012). The higher the inflation rate, the lower the economic growth and investment (in the ratio of investment to GDP) in the long run. Although the negative impact of inflation is relatively small on economic growth, in the long run it will have a substantive impact on the welfare of society, so that high inflation needs to be overcome (Satria, 2012).

Inflation is an important indicator in the economy that cannot be ignored, because it can have a very broad impact on both the economy and the welfare of the people. Therefore, there is a study which states that inflation has an effect on the economic growth of a country, the higher the inflation, the more it will weaken the economy of a country (Kasidi \& Mwakanemela, 2013: Sarel, 
1996: He \& Zhang, 2009). However, there are several studies that show that inflation has no effect on economic growth (Burdekin \& Denzau, 2004: Semuel \& Nurina, 2015).

H2. Inflation affects economic growth

\section{EXCHANGE RATE AND GDP}

Exchange Rate and GDP A stable exchange rate is seen as a measure of a successful industry in a country and is able to increase economic growth. High economic growth can help maintain the level of the country's foreign exchange reserves (Koirala, 2018). The exchange rate reflects the balance of supply and demand against both domestic and foreign currencies. High economic growth, one of which is supported by adequate export growth which increases the exchange rate, because the demand for the national currency increases (Rudiawan \& Meirinaldi, 2019), a good exchange rate will help with capital market liquidity so that foreign investors will also increase Guzman, Ocampo, \& Stiglitz, 2018). However, the decline in the exchange rate reflects a decline in the demand for currency by the international community due to the decline in the national economy or due to increased demand for foreign currency by the public due to its role as an international means of payment.

Export and import financing activities require a means of payment that is legal and valid internationally, it can even be said that the capacity and condition of a country's current economy can be determined by the fluctuation of the exchange rate (Semuel \& Nurina, 2015). In addition, the exchange rate between the currency of a country against the currencies of other countries may fluctuate or fluctuate (Susanto, 2018). Therefore, the exchange rate can affect the country's economic growth (A Assery \& Peel, 1991: Siregar \& S. Rajan, 2004). However, there are several studies showing that the exchange rate does not affect the increase in the country's economy (Willem Thorbecke, 2011: Iwayem \& Fowowe, 2010).

H3. Exchange Rate has an effect on Economic Growth

\section{UNEMPLOYMENT AND GDP}

According to Blanchard (2006: 182-187), the relationship between the unemployment rate and output growth is negative. The relationship between output growth and the unemployment rate is known as Okun's Law, when the unemployment rate is high while resources cannot be allocated optimally, the level of people's income will decrease and people's purchasing power (purchasing power parity) is relatively low and as a multiplier effect, public consumption of output (goods and services) will decrease and will have an impact on economic growth, because when public consumption decreases, it means that demand for goods and services will also decrease and will 
be responded to by producers by reducing the production of goods and services that have an impact. on output and growth.

H4. Unemployment affects economic growth

\section{RESEARCH METHOD}

\section{Types and sources of data}

The type of data used in this study, when viewed from the source, is secondary data, time series data for the annual period 1991 - 2019 and cross-section data covering 8 countries. Secondary data is a historical data structure regarding the variables that have been previously collected and compiled by other parties.

\section{Population and Sample}

The population in this study is the superpowers that are officially registered in the World Bank data. The total number of superpowers according to their types are Australia, China, India, Korea, Japan, Singapore, Thailand, United State America,

The sample is the entire list of individuals in the population and the sample will be taken to be the unit of analysis. In this study, the technique of determining the sample used purposive sampling technique, which is how the sample is drawn based on the criteria chosen by the researcher. The sample criteria selected were:

a. Superpower country

b. World Bank Data reports are published during the study year

c. Available data needed for research, namely: gross domestic product (GDP), Export, Inflation,

Exchange Rate, Unemployment.

\section{Research Variables and Variable Operational Definition}

Variables in research are attributes of a group of objects under study with variations from each object (Sugiarto, 2006). The variables used in this study are gross domestic product as the dependent variable (dependent variable) and independent variable (independent variable) in this study, namely Export (X1), Inflation (X2), Exchange Rate (X3), Unemployment (X4). The data proxies used for each variable are as follows:

\begin{tabular}{|l|l|l|}
\hline Variabel & Satuan & Sumber \\
\hline Gross domestic product & Persen & Laporan World Bank Data \\
\hline Eksport & Persen & Laporan World Bank Data \\
\hline Inflation & Persen & Laporan World Bank Data \\
\hline Exchange Rate & Persen & Laporan World Bank Data \\
\hline Unemployment & Persen & Laporan World Bank Data \\
\hline
\end{tabular}




\section{Data Analysis Techniques}

In this research, the analysis technique used is panel data regression analysis. Panel data is data that combines time series data and cross section data. Time series data is data arranged based on time sequences, such as daily, monthly, quarterly or annual data. Meanwhile, cross-section data is data collected at the same time from several countries. Combining the two types of data can be seen that the dependent variable gross domestic gross (GDPO) consists of several countries (crosssection) but in various time periods (time series). The data collected in this study were from 1991 to 2019 for eight superpowers.

\section{DATA ANALYSIS AND DISCUSSION}

\section{Research Results}

In estimating the Gross Domestic Product (GDP), Export (EKP), Inflation (INF), Exchange Rate (M2), Unemployment (UNP) variables. for the annual period 1991 - 2019 as well as crosssection data covering 8 countries, the best model selection test will be conducted first. The tests carried out include:

Secondary data is a historical data structure regarding the variables that have been previously collected and compiled by other parties. The Chow test was conducted to determine the penel data model to be used between the Cammon Effect Model and the Fixed Effect Model. The results of the estimated Chowt test or Likelihood ratio test can be seen in Appendix $\mathrm{C}$ showing that both the $\mathrm{F}$ test and the Chi-square test are significant (P-value 0,000 is less than 5\%) so that $\mathrm{H} 0$ is rejected and H1 is accepted, so the model to be used is the Random Effect. Model. From these results, it will be followed by a test of results.

The Hausman test was conducted to determine the penel data model to be used between the Fixed Effect Model and the Random Effect Model. This test works by testing whether there is a relationship between the error in the model (composite error) and one or more explanatory (independent) variables in the model.

Correlated Random Effects - Hausman Test

Test cross-section random effects

\begin{tabular}{lccc}
\hline \hline Test Summary & Chi-Sq. Statistic Chi-Sq. d.f. & Prob. \\
\hline \hline Cross-section random & 6.206710 & 4 & 0.1842 \\
\hline \hline
\end{tabular}


The Hausman test results can be seen in the appendix showing that the probability value (Prob.) Cross-section is random. The top table shows the Prob value. The random cross-section is 0.1473 whose value is $>0.05$, so it can be concluded that the Random Effect Model is more appropriate than the Fixed Effect Model.

The results of the regression test with the Random Effect Model are as follows:

\begin{tabular}{ccccc}
\hline \hline Variable & Coefficient & Std. Error & t-Statistic & Prob. \\
\hline \hline EKP & -0.053003 & 0.026580 & -1.994132 & 0.0477 \\
INF & 0.116466 & 0.069638 & 1.672452 & 0.0963 \\
M2 & -0.005627 & 0.002325 & -2.420302 & 0.0166 \\
UNP & -0.331903 & 0.295681 & -1.122506 & 0.2632 \\
C & 7.997738 & 2.047255 & 3.906567 & 0.0001 \\
\hline \hline & & & & \\
R-squared & 0.118539 & Mean dependent var & 0.556136 \\
Adjusted R-squared & 0.097676 & S.D. dependent var & 2.540320 \\
S.E. of regression & 2.413068 & Sum squared resid & 984.0698 \\
F-statistic & 5.681804 & Durbin-Watson stat & 1.459357 \\
Prob(F-statistic) & 0.000258 & & & \\
\hline \hline
\end{tabular}

Source: Eviews test results, 2021 (processed)

a. The value of the Export coefficient $=-0.053003$, the Export variable has a negative regression coefficient on the level of Gross Domestic Product (GDP). This means that if the other independent variables are fixed, then each increase per unit of the Export variable will cause an increase in the Gross Domestic Product (GDP) rate variable. amounting to -0.053003 and vice versa.

b. Inflation coefficient value $=0.116466$ Inflation variable has a positive regression coefficient on the level of Gross Domestic Product (GDP). This means that if the other independent variables are fixed, then each increase per unit of the Inflation variable will cause an increase in the Gross Domestic Product (GDP) rate variable by 0.116466 and vice versa.

c. Exchange Rate coefficient value $=-0.005627$, the Exchange Rate variable has a negative regression coefficient on the level of Gross Domestic Product (GDP). This means that if the other independent variables are constant, then each increase per unit of the 
Exchange Rate variable will cause an increase in the Gross Domestic Product (GDP) rate variable by -0.005627 and vice versa.

d. Unemployment coefficient value $=-0.331903$, the Unemployment variable has a negative regression coefficient against the level of Gross Domestic Product (GDP). This means that if the other independent variables are constant, then each increase per unit of the Unemployment variable will cause an increase in the Gross Domestic Product (GDP) rate variable by -0.331903 and vice versa.

After knowing these results, then the hypothesis will be tested for each variable, including the following:

\section{a. Partial Test (t test)}

The $t$ test is conducted to determine which number of independent variables are individually able to explain and influence the dependent variable. The independent variable is said to have an influence and is significant if the probability value is smaller than the significance level used. Based on the test results, it was found that the estimated value for the Export variable (0.0477), Inflation (0.0963), Exchange Rate (0.0166), Unemployment (0.2632). The significance level used is $5 \%$ or 0.05 , so only two independent variables have a significant effect, namely, Export (X1), Exchange Rate (X3). Meanwhile, the two independent variables, namely, Inflation (X2) Unemployment (X4) did not have a significant effect on the dependent variable.

\section{b. Simultaneous Test (Test F)}

Simultaneous testing (Test F) is used to see the effect of all independent variables on the dependent variable together. The significance level to be used is $5 \%(0.05)$. The influence of the independent variables, namely Export (X1), Inflation (X2), Exchange Rate (X3), Unemployment (X4), on the dependent variable, namely Gross Domestic Product (Y). Based on the test results in the appendix, the F-statistical probability results are 0.00 or less than 0.05 . Thus it can be concluded that in this study all independent variables significantly influence the dependent variable.

\section{Interpretation of Results and Discussion}

From the results of the Random Effect Model estimation, it can be seen that the independent variables, namely Export (EKP), Exchange Rate (M2), have a significant effect on the level of Gross Domestic Product (GDP). Meanwhile, other independent variables, including inflation (INF), Unemployment (UNP), did not have a significant effect on the level of Gross Domestic Product (GDP). 


\section{a. The Effect of Exports on Gross Domestic Product (GDP)}

The t-statistic result shows that exports in China, India, Korea, Japan, Thailand and America have an effect on and not significant to the level of Gross Domestic Product (GDP). The probability value is 0.0477 (less than 5\%), so it can be concluded that $\mathrm{H} 1$ is accepted, meaning that there is an influence between Exports on the level of Gross Domestic Product (GDP), with a coefficient of -0.053003 So that it can be interpreted when there is a $1 \%$ increase in exports, then economic growth will drop by $5 \%$. The export sector plays a major role in economic development (Abdula \& Jaquet, 2002). Exports are various kinds of goods and services that have been produced domestically and sold abroad (Puspitasari, 2014). Exports are one of the foreign sources that are used as a reduction in income and can create labor and increase income (Fannoun \& Hassouneh, 2019). Various economists have stated that increasing exports can increase economic growth because exports are an element of GDP (Md. Sazib Miyan \& Kabir Biplob, 2019).

Exports have an effect on economic growth from two sides, namely from the demand and supply side. In terms of demand, when the export sector employs a number of workers, it will affect the ability of the community to earn income due to the ability of companies to pay wages to workers so that it makes households to increase their consumption, but from the side of advice, exports can be a source of income. funding that encourages investment. Incentives to increase investment and technology will imply differences in productivity in supporting the export sector, in other words, the productivity of marginal factors is expected to be higher than other economic sectors (Sharma \& Panagiotidis, 2005).

On the other hand, it can also increase the company's total production (He \& Zhang, 2009). Research shows that exports have an effect on economic growth (Murindahabi, Qiang Li, Nisingizwe, \& Ekanayake, 2019: G. Dlamini \& V. Dlamini, 2019: Md. Sazib Miyan \& Kabir Biplob, 2019).

\section{b. The Effect of Inflation on the Rate of Gross Domestic Product (GDP)}

The result of t-statistic test shows that inflation in China, India, Korea, Japan, Thailand and America has no significant effect on the level of Gross Domestic Product (GDP), the probability value is 0.0963 (more than 5\%). So it can be concluded that $\mathrm{H} 2$ is rejected, meaning that there is no influence between inflation on the level of Gross Domestic Product (GDP). In a study (Semuel \& Nurina, 2015) which states that inflation has no effect on economic growth. According to research (Pratiwi, 2015 \& Ratnasari, 2016) which states that inflation has a significant negative effect on Indonesia's economic growth, 
high inflation can lead to economic instability, reduce investment, inhibit exports and may have an impact on increasing the unemployment rate. In terms of welfare, high inflation causes a decrease in the real income of the community, especially for workers who have a steady income, so that it has an impact on decreasing the level of public consumption and increasing poverty (Rukmana, 2012). The results of this study are in line with research conducted by Riyat (2012), the inflation rate may not affect economic growth due to the success of a country to suppress inflation at a low level, namely below $10 \%$. therefore, even though the inflation rate does not affect economic growth, if it is allowed to do so until there is an increase in the high inflation rate and even hyper-inflation occurs, this event will affect the economy so that economic growth becomes negative or decreases. The conclusion in the data obtained shows that inflation in China, India, Korea, Japan, Thailand and America tends to have a small average of $0 \%$ to $5 \%$. Low inflation rate does not affect economic growth

\section{c. The Effect of Exchange Rate (M2) on the Rate of Gross Domestic Product (GDP)}

Exchange Rate results in China, India, Korea, Japan, Thailand and America have a significant negative effect on the level of Gross Domestic Product (GDP), with a probability value of 0.0166 (less than 5\%). So it can be concluded that H3 is accepted, meaning that there is an influence between the Exchange Rate on the level of Gross Domestic Product (GDP). In accordance with the results of research (A Assery \& Peel, 1991: Siregar \& S. Rajan, 2004) which argues that the exchange rate can affect the country's economic growth and in line with the exchange rate between the currencies of a country against the currencies of other countries, it can change or change. fluctuates (Susanto, 2018). Export and import financing activities require a means of payment that is legal and valid internationally, it can even be said that the capacity and condition of a country's current economy can be determined by the fluctuation of the exchange rate (Semuel \& Nurina, 2015). Export and import financing activities require a means of payment that is legal and valid internationally, it can even be said that the capacity and condition of a country's current economy can be determined by the fluctuation of the exchange rate (Semuel \& Nurina, 2015).

\section{d. The Effect of Unemployment (UNP) on the Rate of Gross Domestic Product (GDP)}

The results of unemployment in China, India, Korea, Japan, Thailand and America have a significant negative effect on the level of Gross Domestic Product (GDP), with a probability value of 0.2632 (more than 5\%). So it can be concluded that $\mathrm{H} 4$ is rejected, meaning that there is no effect between unemployment on the level of Gross Domestic 
Product (GDP), with a coefficient of -0.331903 . So that it can be interpreted that when there is an increase of $1 \%$ unemployment, then economic growth will decrease by $0.3 \%$. The results of his empirical study show that adding 1 (one) point of unemployment will reduce GDP (Gross Domestic Product) by 2 percent. This means that there is a negative influence between unemployment and economic growth and vice versa economic growth and unemployment. The decline in unemployment reflects inequality. This has distributional consequences. Unemployment is also related to the availability of jobs, the availability of employment is related to investment, while investment is obtained from accumulated savings, saving is the residual income that is not consumed. The higher the national income, the lower the expectation to open up new production capacity which of course will absorb new workers.

From the regression results above, it can be seen that the unemployment variable has an effect on economic growth in Indonesia. This indicates that even though the unemployment rate is increasing, it will not affect economic growth. This is due to use, technology that is getting bigger and productivity is increasing even though the unemployment rate is increasing. This result is in accordance with the results obtained by Schubert and Tunrovsky (2017) which state that in the long run unemployment and economic growth have a weak relationship. Conversely, in the short term the effect of unemployment on economic growth is slightly stronger

\section{CONCLUSIONS AND SUGGESTIONS}

\section{A. Conclusion}

Based on the results of data analysis and previous discussion, the following conclusions can be drawn:

1. The partial test results show:

a. The Export variable has an effect and is not significant to the level of Gross Domestic Product (GDP). Exports are one of the foreign sources that are used as a reduction in income and can create labor and increase income (Fannoun \& Hassouneh, 2019). Other research shows that exports have an effect on economic growth (Murindahabi, Qiang Li, Nisingizwe, \& Ekanayake, 2019: G. Dlamini \& V. Dlamini, 2019: Md. Sazib Miyan \& Kabir Biplob, 2019).

b. Inflation variable has no effect on Gross Domestic Product (GDP). due to the success of a country to suppress inflation at a low level, therefore, even though the inflation rate has no effect on economic growth, if it is left alone until there is an increase in the high inflation rate 
even to hyper inflation, this event will affect the economy so that economic growth becomes negative or decreases.

c. The Exchange Rate variable has a significant negative effect on the level of Gross Domestic Product (GDP), which argues that the exchange rate can affect the country's economic growth and in line with the exchange rate between the currency of a country against the currencies of other countries, it can fluctuate or fluctuate (Susanto, 2018 ). Export and import financing activities require a means of payment that is legal and valid internationally, it can even be said that the capacity and condition of a country's current economy can be determined by the fluctuation of the exchange rate (Semuel \& Nurina, 2015). Export and import financing activities require a means of payment that is legal and valid internationally, it can even be said that the capacity and condition of a country's current economy can be determined by the fluctuation of the exchange rate (Semuel \& Nurina, 2015).

d. Unemployment variable has a negative and insignificant effect on the level of Gross Domestic Product (GDP). This indicates that even though the unemployment rate is increasing, it will not affect economic growth. This is due to use, technology that is getting bigger and productivity is increasing even though the unemployment rate is increasing. 


\section{REFERENCES}

Abdul, N. R. (2019). Relationship Between Major Macroeconomic Variables and Economic Growth: A case of Pakistan during 1976-2016. WALIA journal, 21-26.

Abdula \& Jaquet. (2002). Exports and Economic Growth: Cointegration and Causality Evidence for Co^te d'Ivoire. African Development Bank, 1-17.

Bhagwati, J. (1988). Protectionism. Cambridge: MA: MIT Press.

Fannoun, Z. \&. (2019). The Causal Relationship between Exports, Imports and Economic Growth in Palestine. Journal of Reviews on Global Economics, 258-268.

He, D. \&. (2009). How Dependent is the Chinese Economy on Exports and in What Sense has its Growth been Export-Led? . Journal of Asian Economics, 87-104.

Jhingan. (2010). Ekonomi Pembangunan dan Perencanaan. Jakarta: Geafindo.

Md. Sazib Miyan, \&. K. (2019). Revisiting Exports, Imports and Economic Growth Nexus: Empirical Evidence from Bangladesh (1981-2017). Modern Economy, 523-536.

Nainggolan, D. S. (2019). Peranan Kebijakan Moneter Mengendalikan Suku Bunga dan Inflasi serta Pengaruhnya terhadap Pertumbuhan Ekonomi di4 Negara Asia (Singapura, Korea Selatan, dan Indonesia). Seminar Nasional \& Call For Paper Seminar Bisnis Magister Manajemen, 244-257.

Nurina. (2016). Analisis Pengaruh Inflation, Interest Rate, dan Exchange Rate Terhadap Gross Domestic Product (GDP) di Indonesia. Petra Business \& Management Review, 48-58.

Prastity, N. \&. (2013). The Effect Foreign Direct Invesment and Trade . Kajian, 255-270.

Puspitasari, G. (2014). The Effect of Gross Domestic Produc (GDP) and Exchange Rate of Major Trading Partners on Indonesia Natural Rubber Export 2000-2012. . Kajian, 21-31.

Rukmana, I. (2012). Pengaruh Disparitas Pendapatan, Jumlah Penduduk dan Inflasi . Economics Development Analysis Journal, 26-34.

Semuel, H. \&. (2015). Analysis of the Effect of Inflation, Interest Rates, and Cointegration and Causality Evidence (1971-2001). Review of Development Economics, 232-248.

Sharma, A, P. (2005). An Analysis of Exports and Growth in India:Cointegration and Causality Evidence (1971-2001). Review of Development Economics, 232-248.

Todaro, M. P., \& Smith, S. C. (2003). Pembangunan Ekonomi di Dunia Ketiga. . Jakarta: Edisi Kedelapan Erlangga. 